\title{
A New Origin of the Chief Cells in the Swine Fundic Gland
}

By

\section{Masatake IMAI, Taizo SHIBATA and Keiichi MORIGUCHI}

\author{
Department of Anatomy, Kanazawa Medical University, \\ Uchinada-machi, Kahoku-gun, Ishikawa 920-02, Japan
}

Key words: Mucous neck cell, Immature chief cell, Mature chief cell, Strongly PAS-positive cell, Pepsinogen granules, Swine

Summary: We demonstrated a new origin of chief cells in the swine fundic glands.

1. Besides the mucous neck cells, the characteristic cells of the swine fundic gland were found to be filled with strongly PAS-positive substance, and to differentiate into the chief cells.

2. The strongly PAS-positive cells were distributed between the chief cells and parietal cells, but not in the mucous neck cell zone or the upper portion of the glandular body.

3. The nuclei of the strongly PAS-positive cells were flat and extremely dark, while those of immature and mature chief cells were fairly clear and either oval or round.

4. Immature chief cells in the upper portion of the glandular body contained PAS-positive substance in the supranuclear portion, however, the corresponding cells in the middle regions of the glandular body did not despite the presence of strongly PAS-positive cells nearby.

5. Strongly PAS-positive cells in the glandular body were irregular in shape, while immature chief cells accompanying them were cuboidal. In the basal region of the gland, strongly PAS-positive cells and mature chief cells were either cuboidal or short columnar.

6. The PAS-positive substance in strongly PAS-positive cells was seen to gradually decrease in quantity with differentiation of these cells into mature chief cells. At the end-stage of this process, the substance became undetectable and a reticulate framework formed in the cytoplasm. Nuclei became quite clear and assumed a round or oval shape in the resultant mature chief cells.

7. Coarse, dark blue pepsinogen granules were detected in mature chief cells. Strongly PAS-positive cells also contained pepsinogen granules, but these were smaller in comparison and claret colored.

8. The differentiation of strongly PAS-positive cells into mature chief cells is thought to take place most actively in the base of the fundic gland, because cells containing variable amounts of PAS-positive substance were observed in this area, i.e. undifferentiated cells contain large quantities of PAS-positive substance, but progressively less and less as differentiation progresses.

9. It is presumed that immature chief cells originating from mucous neck cells do not differentiate in the basal portion of the gland since the former were not detected in this region. Probably, half-matured cells in the lower part of the glandular body (seen as small cells with reticulate frameworks) move to the glandular base where the transformation into mature chief cells is completed.

10. Despite the two origins of mature chief cells, from mucous neck cells or strongly PAS-positive cells, there were no differences in final histological and histochemical 
characteristics; all were large, either cuboidal or short columnar cells, and had fairly clear round or oval nuclei, a cytoplasmic reticulate framework, coarse, dark blue pepsinogen granules, and a negative reaction to PAS, AB (pH 2.5 and 0.5) and PAS-AB (pH 2.5).

11. Some strongly PAS-positive cells were AB (pH 2.5) negative, while others showed varying degrees of reactivity. These differences may be related to variation in the stage of differentiation of the same kind of cell. Such cells were distributed in the base portion of the glands.

12. The strongly PAS-positive cells reacted negatively to $\mathbf{A B}$ (pH 0.5 ).

13. Various reaction colors were produced by PAS-AB (pH 2.5) staining depending on the degree of reaction with $\mathrm{AB}$ ( $\mathrm{pH}$ 2.5). It was presumed that red stained cells were the least differentiated.

14. Mucous neck cells reacted strongly with $\mathrm{AB}$ (pH 2.5 and 0.5 ), while immature chief cells were negative for these stains.

15. Staining with PAS-AB (pH 2.5) produced a violet colour in mucous neck cells and a red colour in immature chief cells.

16. A survey of previous investigations of the fundic gland in man, Japanese macaque, crab-eating monkey, dog, cat, rabbit, horse, cow, mouse and rat revealed no evidence for the presence of strongly PAS-positive cells such as those described here in the swine.

The mucous neck cells have been described as the progenitors of the chief cells in the fundic gland. This paper presents findings that suggest that strongly PAS-positive cells in the swine fundic gland also change into chief cells.

\section{Materials and Methods}

Five adult swines from a slaughter-house were used in this study. Samples were taken in as fresh a state as possible from the fundic gland region, and fixed in buffered formalin (4) and methyl alcohol saturated with barium hydroxide for pepsinogen granules (1). The tissues were embedded in paraffin and cut into sections of about $6 \mu$ thickness. PAS-, AB (pH 2.5 and 0.5)-, PAS-AB (pH 2.5), H-E stains, and Bowie's and Bowie's -PAS staining methods for pepsinogen granule analysis were employed.

\section{Observations}

Cells filled with strongly PAS-positive substance were distributed singly or in aggregates among the chief cells and parietal cells (Figs. 1 and 3). They frequently formed groups in the basal portion of the gland (Figs. 2, 4, 5 and 6) but were not observed in the mucous neck cell zone (Fig. 9) or the upper portion of the glandular body (Fig.
10).

These cells had flat and extremely dark nuclei (Fig. 7) and, in the main body of the gland, were large and of an irregular form, in contrast to the immature chief cells which were smaller and had cuboidal shapes and fairly clear oval or round nuclei (Fig. 8). Strongly PAS-positive cells in the region at the base of the gland were short columnar.

The strongly PAS-positive cells were filled with PAS-positive substance (Figs. 1-6), while the some substance in the immature chief cells in the upper portion of the glandular body was located in the supranuclear portion (Fig. 10), whereas corresponding cells in the middle and lower areas were found to have lost this compound (Fig. 1).

In the basal region, strongly PAS-positive cells contained variable amounts of PASreactive material, with a general reduction in quantity accompanying the progressive differentiation into mature chief cells and ending with total disappearance of this substance. Maturation involved the formation of a reticulate framework in the 
cytoplasm, and gradual transformation of flat, dark nuclei into semi-clear oval or round forms (Figs. 11 16).

Application of Bowie's method for detection of pepsinogen granules showed that these were fine and claret colored in the strongly PAS-positive cells (Figs. 23 and 24). A combination of Bowie's method and PAS staining dyed pepsinogen granules in the strongly PAS-positive cells a different colour to those of mature chief cells. Specifically, the former were fine and stained dark purple (Fig. 22), while the latter were coarse and became light blue (Figs. 20 and 21).

Pepsinogen granules contained in mucous neck cells and immature chief cells were finer than their counterparts in mature chief cells (Figs. 17 and 18). Generally, the strongly PAS-positive cells reacted positively to PAS but mature chief cells were PAS-negative when this staining procedure was used (Fig. 19).

Some strongly PAS-positive cells were AB (pH 2.5) negative, while others showed varying degrees of positive reaction as evidenced by the large number of colours produced. Most of these cells were distributed in the basal portion of the gland.

Strongly PAS-positive cells reacted negatively to $\mathrm{AB}$ ( $\mathrm{pH} 0.5$ ) except in extremely rare cases, where groups of the same cell type were moderately stained.

In the case of mucous neck cells, reaction to $\mathrm{AB}$ ( $\mathrm{pH} 2.5$ and 0.5 ) staining was strong, while immature chief cells were found to be negative for $A B$ at these $\mathrm{pH}$ 's.

Mature chief cells in the basal region of the fundic gland were large and cuboidal or short and columnar, and had cytoplasmic reticulate frameworks. Their nuclei were oval or round in form and quite clear (Figs. $5,6,12 \sim 16)$. These cells reacted negatively to PAS, AB (pH 2.5 and 0.5) and PAS-AB (pH 2.5) and contained coarse, dark blue pepsinogen granules. No differences were seen between mature chief cells despite differences in progenitor, i.e. mucous neck cells or strongly PAS-positive cells.

\section{Discussion}

In the early literature (1887 1947), numerous scholars $1,2,3,6,7,9,10,12,13,19$, $20,21,22,23,24,26,28,32,33,34,35,36,37$, $38,39)$ assumed that mucous neck cells were generated through transformation of chief cells. Ishizawa $(1951)^{18)}$ also made this suggestion, but presented an alternate theory wherebye mucous neck cells, conversely, replenish chief cells. A later radioautographic study by Messier $(1960)^{25)}$ using thymidine- ${ }^{3} \mathrm{H}$ and conducted in the rat stomach, concluded that the chief cells did not originate from mucous neck cells. On the other hand, Myhre $(1960)^{31)}$ and Hunt and Hunt $(1962)^{14)}$ used similar experimental procedures to find evidence for the transformation of mucous neck cells into chief cells in the rat. Further support for this was provided by Townsend $(1961)^{43)}$ in a series of histological and histochemical studies on the regeneration of established gastric mucosa of the rat. Similarly Miyake et al. $(1963)^{27)}$ investigated the hamster stomach using thymidine ${ }^{3} \mathrm{H}$, radioautography $\left({ }^{3} \mathrm{H}-\mathrm{TdR}\right)$ and electron microscopy to find that the chief cells were formed from undifferentiated cells distributed in the neck cell regions of the glands. A more specific conclusion was drawn by Corpron (1966) ${ }^{5}$ ) after ultrastructural examination of the gastric mucosa in normal and hypophysectomized rats; this author suggested that the chief cells differentiated either directly from undifferentiated cells, or from mucous neck cells themselves derived from undifferentiated cells.

Histological and histochemical investigations (including Bowie's method) of the fundic glands in seven men, six Japanese monkeys, three adult dogs, and one one-month-old and one three-month-old 
puppies, have demonstrated the presence of pepsinogen granules in the mucous neck cells and chief cells (Imai et al., 1967) ${ }^{15,16)}$. Moreover, these studies confirmed that immature chief cells were distributed among the mucous neck cells and mature chief cells. On the basis of these findings, it was concluded that mucous neck cells differentiated into mature chief cells. On associated assertion that mucous neck cells also differentiated into foveolar epithelial cells was later retracted as erroneous by the same authors $(1982)^{17)}$.

In 1976, Hattori et al. ${ }^{11)}$ reported that mucous neck cells were the progenitors of chief cells after carrying out a tritated thymidine autographic study on the golden hamster. The same conclusion was reached by Fujita et al. $(1983)^{8)}$ by applying ${ }^{3} \mathrm{H}-\mathrm{TdR}$ to the adult hamster. Suzuki et al. $(1983),{ }^{41,42)}$ Suganuma et al. $(1985)^{40)}$ and Murata et al. $(1987)^{29)}$ determined that the mucous neck cell was the precursor to the chief cell in the rat stomach by confirming the existence of another cell type distributing between mucous neck cells and chief cells, and also by finding pepsinogen I activity in the mucous neck cells, chief cells and intermediate forms of these. This was achieved by means of the periodic acidthiocarbohydrazid-silver proteinate procedure, the lectinferritin method, the postembedding immunoferritin method, and by use of low-temperature embedding resin, Lowicryl $\mathrm{K} 4 \mathrm{M}$, and subsequent staining of samples with lectin/colloidal-gold (CG) conjugates. These authors $(1988)^{30)}$ also performed routine transmission electron microscopy with PA-TCH-SP and lectin colloidal gold conjugates (HPA, GSA II, PNA) staining, using ultrathin sections of rat fundic gland, and concluded that mucous neck cells were precursors of chief cells.

Cornaggia et al. $(1986)^{4)}$ also detected pepsinogen I activity in human mucous neck cells, and both immature and mature chief cells by means of electron immunocytochemistry.

From the results presented above, we consider it to be well established that chief cells arise through the differentiation of mucous neck cells. In addition, we posit the existence of a distinctly different germinal cell precursor of chief cells in the swine fundic gland. These cells were filled with a strongly PAS-positive substance, and were tentatively labeled strongly PAS-positive cells. They occurred singly among the chief cells and parietal cells in the glandular body, but formed groups distributed among the mature chief cells in the basal region. None were detected in the mucous neck cell zone. The form of these cells was irregular in the body of the gland, and cuboidal or short columnar in the glandular base. Nuclei were flat and extremely dark.

The mucous neck cells were cuboidal, had round or oval, fairly clear nuclei, and, when fronting onto the glandular lumen, reacted strongly with PAS. Immature chief cells derived from the mucous neck cells were cuboidal or short columnar, and also had round or oval nuclei, which were fairly clear. In the upper portion of the glandular body, the supranuclear areas of these cells showed strong PAS reaction, while, although strongly PAS-positive cells were present, no PAS-positive material was detected in immature chief cells of the lower region of the fundic gland.

Such characteristics make strongly PASpositive cells in the glandular body easily distinguishable from mucous neck cells and immature chief cells. Immature chief cells derived from mucous neck cells were absent in the basal portion of the gland, and all the cells in this area that reacted with PAS were strongly PAS-positive cells. The quantity of PAS-positive substance in these cells, however, varied and was undetectable in some cases. These facts are interpreted as showing that the strongly PAS-positive cells 
differentiate into PAS-negative mature chief cells. Concurrent with this process was the formation of a reticulate framework in the cytoplasm of the latter and the gradual transformation of flat, dark nuclei into clear round or oval nuclei.

Strongly PAS-positive cells reacted to $\mathrm{AB}$ (pH 2.5) with varying intensities (even negatively), as evidenced by the wide range of reaction colors observed. Red, light purple, violet, and dark blue appeared by PAS-AB ( $\mathrm{pH} 2.5$ ) staining. These colors reflect differences in the degree of cell differentiation, with red stained cells being the least differentiated, and $\mathrm{AB}(\mathrm{pH} 2.5)$ negative. When $\mathrm{AB}$ (pH 0.5) treatment was applied, strongly PAS-positive cells reacted negatively. Strong staining was noted in mucous neck cells in response to $\mathrm{AB}$ ( $\mathrm{pH} 2.5$ and 0.5 ), but none was observed in immature chief cells.

Mature chief cells have two progenitors, mucous neck cells and strongly PAS-positive cells, but once differentiated are indistinguishable from each other. All such matured chief cells reacted negatively to PAS, AB (pH 2.5 and 0.5), and PAS-AB (pH 2.5).

This differentiation of strongly PASpositive cells into mature chief cells was generally seen to take place in the glandular basal region, whereas immature chief cells dervied from mucous neck cells were undetectable there. It is probable that the latter cells are changed into half-matured forms within the body of the gland before being moved into the basal area, where the final stages of maturation are completed. We observed few small cells with reticulate frameworks in the middle portion of the glandular body.

Yasuda et al. $(1966)^{44,45)}$ demonstrated the presence of pepsin in the chief cells of the swine fundic gland by means of a fluorescent antibody technique, but could not confirm its existence in the mucous neck cells.

In the present study, pepsinogen granules were found in the mucous neck cells, immature chief cells and mature chief cells in the swine fundic gland after the application of Bowie's staining method. It is believed that these granules gave some indication of the degree of cell differentiation since they were coarse and dyed dark blue in the case of mature chief cells, but were fine and claret colored in the other cell types. Since fine, claret colored (i.e. immature) pepsinogen granules were also noted in the strongly PAS-positive cells, these were considered to be immature chief cells of a quite distinct type from the immature chief cells originating from mucous neck cells. Accordingly, there are two completely separate origins of the chief cells in the swine fundic gland.

A review of previous investigations of the fundic gland in man, Japanese macaques, crab-eating monkey, dogs, cats, rabbits, horses, cows, mice, and rats has revealed that no such strongly PAS-positive cells have been described in these species. Therefore, the swine is the only animal yet shown to have two kinds of chief cell precursors. Moreover, we propose that the so-called swine cardiac glands, located throughout a fairly wide area adjacent to the proventriculus, are fundic glands which remain at an undifferentiated stage of development. The basis for this conclusion was the observation of small, claret colored pepsinogen granules in the grandular cells in the neck, body and basal regions of these glands. Alternatively stated, many fundic glands neighbouring the proventriculus in the swine are unable to produce mature pepsinogen granules, and are thus immature.

\section{References}

1) Boas, G.: Diagnostik und Therapie der 
Magenkrankheiten. 1894 (cite from Ohishi).

2) Boeckelmann W.A.: Untersuchungen zur pathologischen Anatomie des menscblichen Magens in Fällen von Ulcus und Carcinoma bei bekannter chemischer und motorischer Funktion. Z. klin. Med., 44: 128, 1902 (cite from Plenk)

3) Borst: Pathologische Histologie, 1923 (cite from Plenk).

4) Cornaggia, M., Capella, C., Riva, C., Finzi, G. and Solua, E.: Electron immunocytochemical localization of pepsinogen I (Pg I) in chief cells, mucous neck cells and transitional mucous-neck/chief cells of the human fundic mucosa. Histochemistry. 85: 5-11, 1986.

5) Corpron, R.E.: The ultrastructure of the gastric mucosa in normal and hypophysectomized rats. Amer. J. Anat., 118: 53-63, 1966.

6) Einhorn, M.: A further contribution to our knowledge of the histology of the gastric mucosa in pathological conditions of this organ. Amer. J. microsc. Sci., 124: 571-589, 1902 (cite from Plenk).

7) Ewald, C.A.: Klinik der Verdauungskrankheiten Bd. 2, 1893 (cite from Plenk).

8) Fujita, H. and Tamura, S.: Some findings on the fine structure of surface mucous epithelium and fundus glands of Hamster stomach. Acta Anat. Nippon., 58: 316, 1983 (in Japanese).

9) Hamperl, H.: Über erworbene Heterotopien ortsfremden Epithels im Magendarmtrakt. Beitr. path. Anat., 80: 307-335, 1928 (cite from Plenk).

10) Harvey, B.C.H.: A study of the structure of the gastric glands of the dog and of the changes which they undergo after gastroenterostomy and occulusion of the pylorus. Amer. J. Anat., 6: 207-243, 1907.

11) Hattori, T. and Fujita S.: Triated thymidine autoradiographic study on cellular migration in the gastric gland of the golden hamster. Cell and Tissue Research. 172: 171-184, 1976.

12) Hayem, G.: Gastritis parenchymatosa. Allg. Wien, med. Ztg., 2: 17, 1894 (cite from Plenk).

13) Heyrowsky, H.: Histologische Untersuchungen der Magneschleimhaut bei Ulcus ventriculi und Carcinom. Dtsch. Z. Chir. 122: 359-392, 1913 (cite from Plenk).

14) Hunt, T.E. and Hunt, E.A.: Radioautographic study of proliferation in the stomach of the rat using thymidine- $\mathrm{H}^{3}$ and compound $48 / 80$.
Anat. Rec., 142: 505-517, 1962.

15) Imai, M., Shibata, T. and Mineda, T.: Histological and histochemical investigations on the stomachs in man, Japanese monkey (Macaca fuscata yakui) and some other kinds of animals. Report II. What is the mucous neck cell? Okajimas Fol. Anat. Jpn, 43: 103-117, 1967.

16) Imai, M., Shibata, T. and Mineda, T.: Histological and histochemical investigations on the stomach in man, Japanese monkey (Macaca fuscata yakui) and some other kinds of animals. Report III. The so-called immature chief cell. Okajimas. Fol. Anat. Jpn., 43: 119-131, 1967.

17) Imai, M., Shibata, T. and Higashi, M.: Once again, what is the mucous neck cell? Okajimas Folia Anat. Jpn., 59: 137-140, 1982.

18) Ishizawa, M.: Manual of histology, Vol. II: 243-244, 1951 (in Japanese).

19) Konjetzny.: Die Entzündungen des Magens. Henke-Lubarschs Handb. d. spez. path. Anat. 4, 1928 (cite from Plenk).

20) Lauche, A.: Die Heterotopien des ortsgehörigen Epithels in Bereiche des Verdauungskanals. Virchows Arch., 252: 39-88, 1924 (cite from Plenk)

21) Lehner, J.: Zur Bemerkung und Charakterisierung der Magendrüsen. Wien klin. Wschr., 41: 702, 1928 (cite from Ohishi).

22) Lettule, M.: Anatomie pathologique générale des lesions inflummatoires. Bouchard, Pathologie general, 3 II: 553-642, 1900 (cite from Plenk).

23) Leuk.: Untersuchungen zur pathologischen Anatomie des menschlichen Magens mit Berücksichtigung der praktischen Verwertbarkeit anatomisch diagnostizierter Magenschleimhautstückchen. Z. klin. Med., 37: 296, 1899 (cite from Plenk).

24) Lubarsch, O.: Anatomischer Beitrag zu: F. Martins, Achylia gastrica, 1897 (cite from Plenk).

25) Messier, B.: Radioautographic evidence for the renewal of mucous cell in the gastric mucosa of the rat. Anat. Rec., 136: 242, 1960.

26) Meyer, G.: Zur Kenntnis der sog. "Magenatrophie". Z. klin. Med., 16: 366, 1899 (cite from Ohishi).

27) Miyake, K., Kaku, H., Kojima, A. and Fujita, S.: Studies on the "Generative cell" and its kinetics in the epithelium of gastric mucosa by means of ${ }^{3} \mathrm{H}$-thymidine flash labeling autoradiography and electron microscope. Tr. 
Soc. Path. Jap., 52: 186, 1963 (in Japanese).

28) Moszkowicz, L.: Regeneration und Krebsbildung an der Magenschleimhaut (Grundlagen einer biologischen Krebstheorie.). Arch. klin. Chir., 132: 558-620, 1924 (cite from Plenk).

29) Murata, F., Suganuma, T., Tsuyama, S. and Ihida, K.: The mucous neck cell of the fundic gland is the precursor cell of the chief cell. Acta Anat. Nippon. 62: 204, 1987 (in Japanese).

30) Murata, F., Suganuma, T., Tsuyama, S. and Ihida, K.: Mucous neck cells: proposal that mucous neck cell are the precursor cells of the chief cells-Studies based on glycoconjugate cytochemistry. Acta Anat. Nippon. 63: 12-19, 1988 (in Japanese).

31) Myhre, E.: Regeneration of the fundic mucosa in rats: V. An autoradiographic study on the effect of cortisone. Arch. path., 70: 476-485, 1960 (cite from Corpron).

32) Ohishi, K.: Cytological studies on the human gastric glands. III. Cytological studies on the mucous neck cells. Diss., Tokyo Women's Med. Coll. 1-37, 1947 (in Japanese).

33) Oshikawa.: Über die Magenschleimhaut bei gastroenterostomierten Hunden mit besonderer Berücksichtigung der Bizzozeroschen Spirochätenbefunde, Arch. klin. Chir., 124: 559-564, 1923 (cite from Plenk).

34) Pasehkis, K. and Orator, V.: Beitrag zur normal Histologie des menschlichen Magens (Versuch einer Histotopographie). Z. Anat., 67: 494-516. 1923 (cite from Plenk)

35) Plenk, H.: Der Magen. Möllendorffs Handb. d. mikrosk. Anat. d. Menschen. V-2: 88-234, 1932.

36) Popoff, P.M.: Über Magenkatarrh. Z. klin.
Med., 32: 389, 1897 (cite from Plenk)

37) Sachs, A.: Zur Kenntnis der Magenschleimhaut in krank haften Zustanden. Arch. f. exper. Path., 22: 155, 1887 (cite from Ohishi).

38) Schmidt, A.: Ein Fall von Magenschleimhautatrophie nebst Bemerkungen über sogenannte "schleimige Degeneration der Drüsenzellen des Magens". Dtsch. med. Wschr., 21: 300, 1895 (cite from Ohishi).

39) Stoerck, O.: Über Gastritis chronica. Wien. klin. Wschr, 855-860, 1922 (cite from Plenk)

40) Suganuma, T., Tsuyama, S. and Murata, F.: Glycoconjugate cytochemistry of the rat fundic gland using lectin/colloidal-gold conjugates and Lowicryl K4M. Histochemistry, 83: 489-495, 1985.

41) Suzuki, S., Furihata, C., Tsuyama, S. and Murata, F.: Immunocytochemical localization of pepsinogen in rat stomach. Histochemistry, 79: 167-176, 1983.

42) Suzuki, S., Tsuyama, S. and Murata, F.: Cells intermediate between mucous neck cells and chief cells in rat stomach. Cell Tissue Res., 233: 475-484, 1983.

43) Townsend, S.F.: Regeneration of gastric mucousa in rats. Am. J. Anat., 109: 133-147, 1961.

44) Yasuda, K. and Suzuki, T.: Distribution of pepsin in the stomach, demonstrated by means of fluorescent antibody technique. Acta Anat. Nippon., 41: 171, 1966 (in Japanese).

45) Yasuda, K., Suzuki, T. and Takano K.: Localization of pepsin in the stomach revealed by fluorescent antibody technique. Okajimas Folia Anat. Jpn, 42: 355-367, 1966. 


\title{
Explanation of Figures
}

\author{
(All relate to swine)
}

\section{Plate I}

Fig. 1. A large number of strongly PAS-positive cells $(\uparrow)$ are distributed in the middle region of the fundic gland. PAS staining. $\times 105$.

A: Immature chief cells disappeared along with PAS-positive substance.

B: Parietal cells

Fig. 2. Strongly PAS-positive cells $(\uparrow)$ in the fundic gland. PAS staining. $\times 138$

A: Parietal cells.

B: Chief cells.

Fig. 3. Strongly PAS-positive cells (A), and mature chief cells (B) in the basal portion of the fundic gland. PAS staining. $\times 420$

Fig. 4. Aggregates of strongly PAS-positive cells (A), and chief cells (B). PAS staining. $\quad \times 420$ The nuclei of strongly PAS-positive cells are unrecognizable after PAS staining.

Fig. 5. Groups of strongly PAS-positive cells (A) and mature chief cells (B). Reticulate frameworks are evident in the mature chief cells. PAS staining. $\times 693$

Fig. 6. Clusters of strongly PAS-positive cells (A), and reticulate frameworks in mature chief cells (B). PAS staining. $x 1,050$

Fig. 7. Nuclei ( $\uparrow$ ) of strongly PAS-positive cells. They are flattened and extremely dark. H-E staining. $\times 792$

Fig. 8. Nuclei of mucous neck cells (A) and immature chief cells (B). These are round or oval, and fairly clear. H-E staining. $\times 792$ 
Plate I

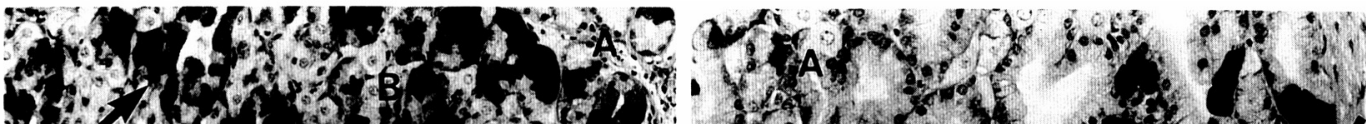
y.3.

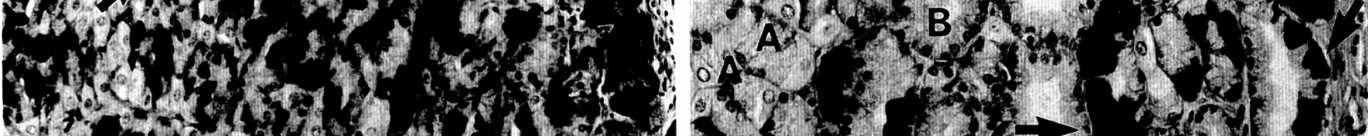
Fon

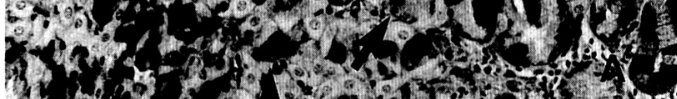

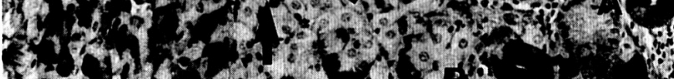

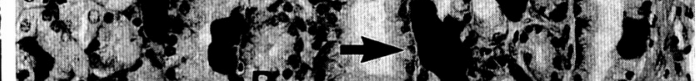

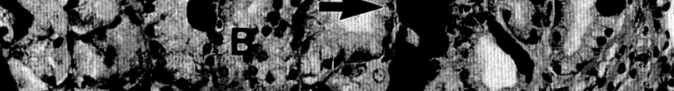

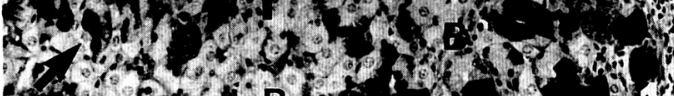

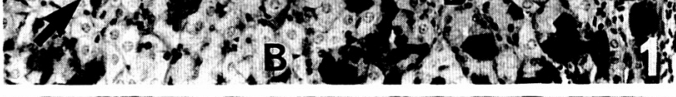

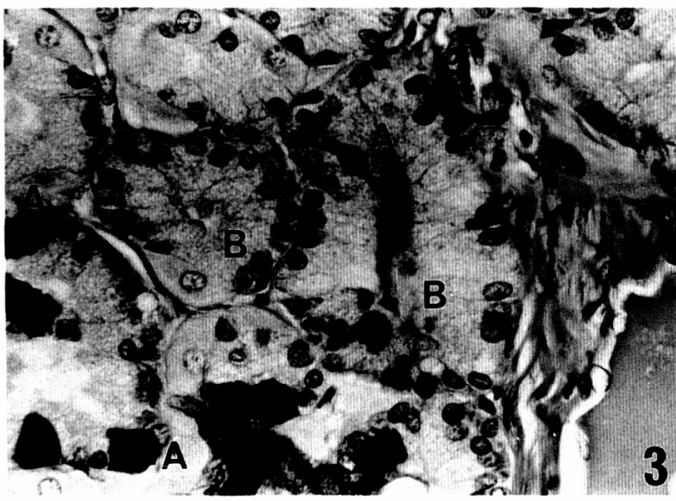

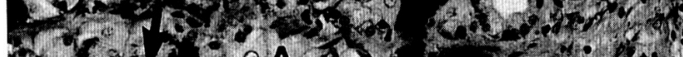

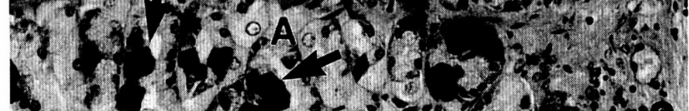

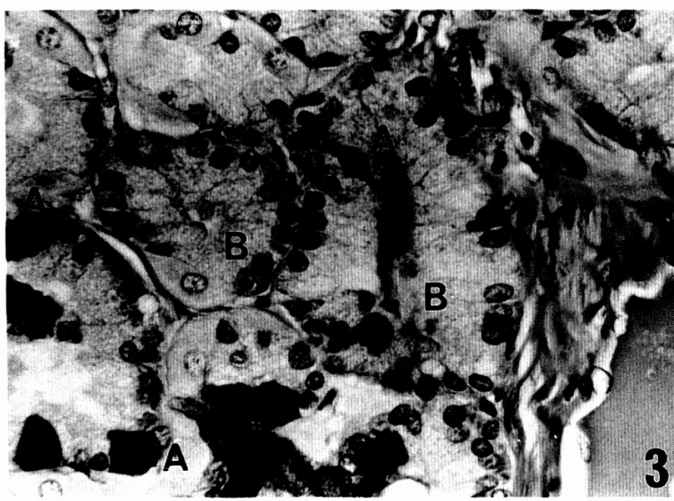
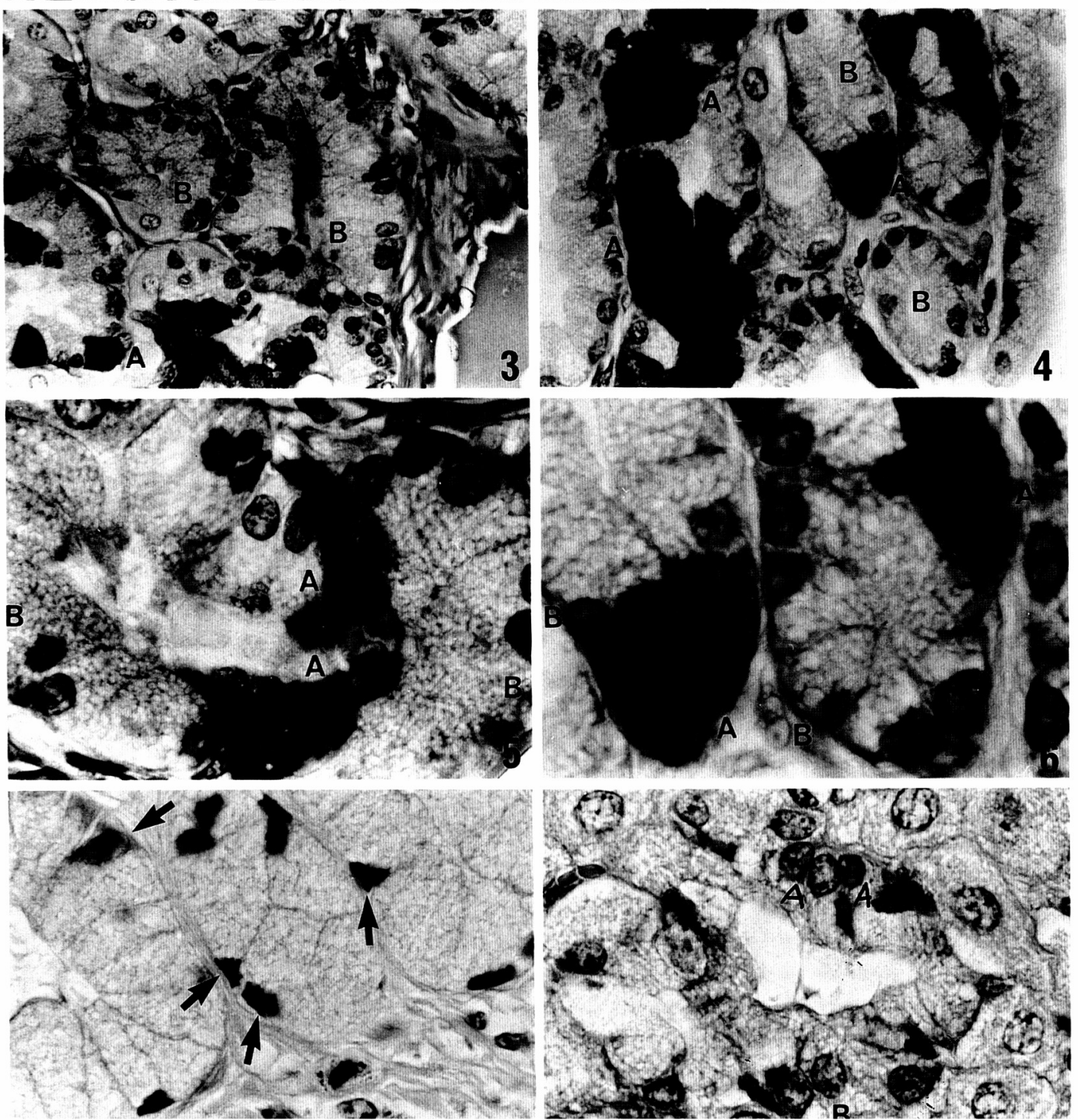


\section{Plate II}

Fig. 9. A narrow area of mucous neck cells fronting the glandular lumen reacted strongly to PAS ( $\uparrow$ ). PAS staining. $\times 277$

Fig. 10. Immature chief cells in the upper portion of the glandular body were filled with PAS-positive substance. PAS staining. $\times 420$

A: Parietal cell.

Fig. 11. Strongly PAS-positive cells (A) and corresponding cells with reduced PAS-positive substance (B). PAS staining. $\times 277$

Figs. 12 16. Strongly PAS-positive cells with reduced PAS-positive substance $(\uparrow)$ and formation of reticulate framework. A small quantity of PAS- positive substance still remains in the margins of cells fronting the glandular lumen. Nuclei are columnar, fairly dark and smaller than those of mature chief cells (A). PAS staining.

Figs. 12, 14 and $15: \times 1,050$, Figs. 13 and $16: \times 693$

B: Parietal cell. 

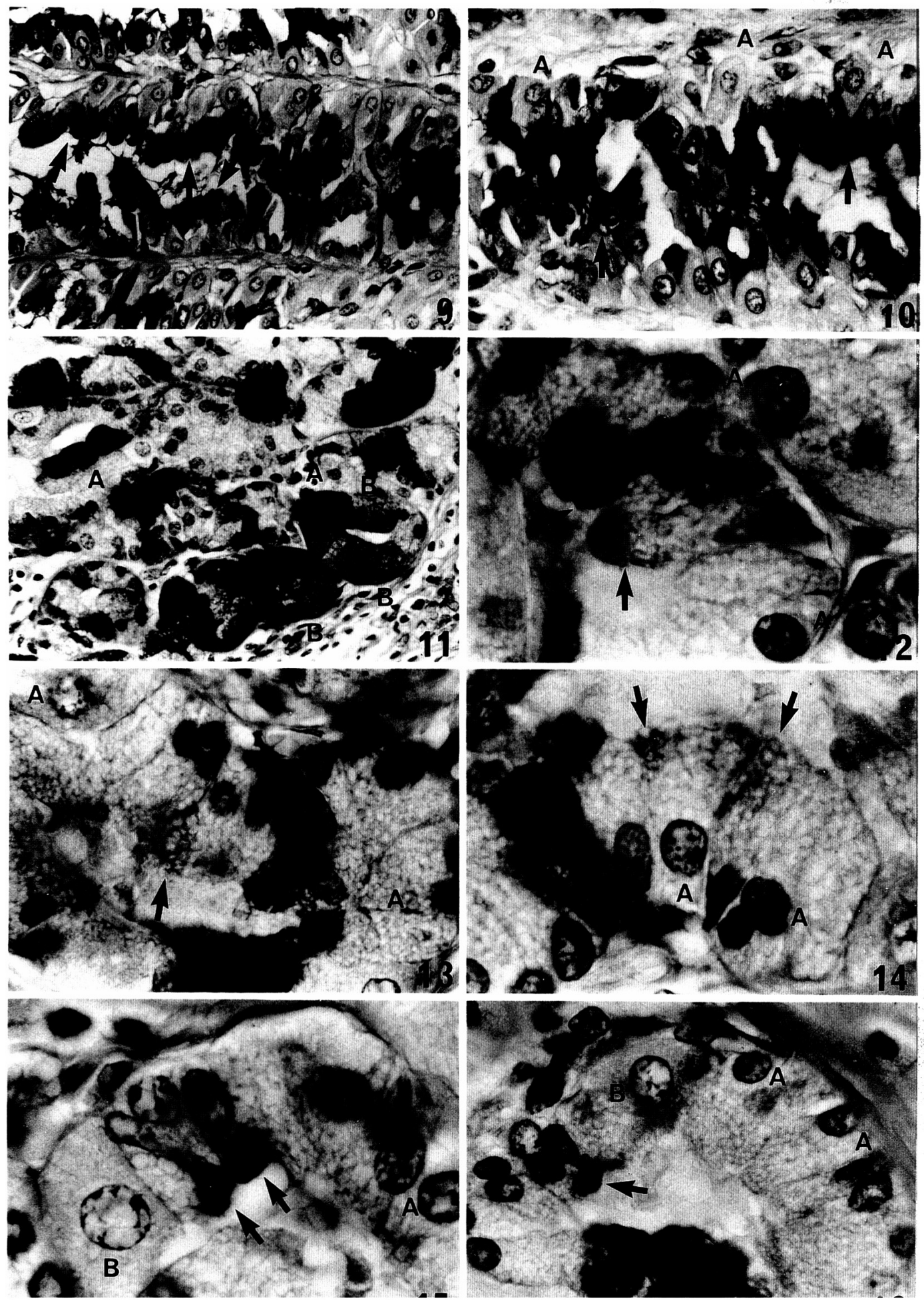


\section{Plate III}

Fig. 17. Fine pepsinogen granules $(\uparrow)$ in mucous neck cells. Bowie-PAS staining. $\times 1,050$

Fig. 18. Fine pepsinogen granules in immature chief cells (A). Such granules are coarse in mature chief cells (B). Bowie-PAS staining. $\times 1,050$

Fig. 19. Pepsinogen granules in mature chief cells in the basal portion of the fundic gland.

$\uparrow$ : Strongly PAS-positive cells.

Bowie-PAS staining. $\times 1,050$

Figs. 20 21. Pepsinogen granules in mature chief cells in the basal portion of the fundic gland. Bowie-PAS staining. $\times 1,050$.

Fig. 22. Pepsinogen granules in strongly PAS-positive cells. Bowie-PAS staining. $\times 1,050$

Fig. 23. Strongly PAS-positive cells in the fundic gland. PAS staining. $\times 52$

Fig. 24. Pepsinogen granules in the same area shown in Fig. 23. Bowie staining method for pepsinogen granules. $\times 420$ 
Plate III
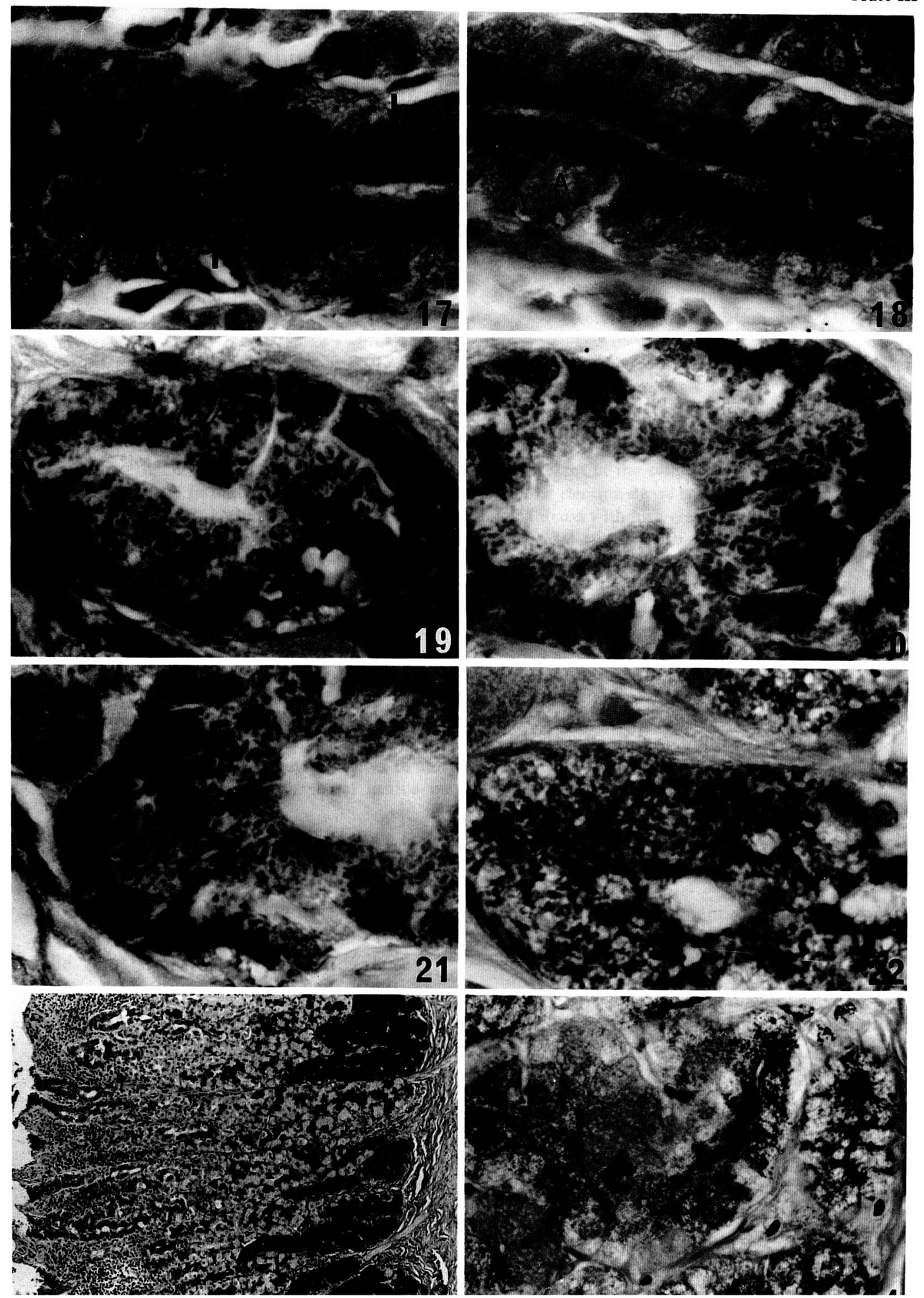